The Beta-Adrenergic Receptors 


\title{
The Receptors
}

\author{
Series Editor \\ David B. Bylund
}

University of Nebraska Medical Center, Omaha, NE

\section{Board of Editors}

S. J. Enna

Nova Pharmaceuticals

Baltimore, Maryland

Morley D. Hollenberg

University of Calgary

Calgary, Alberta, Canada
Bruce S. McEwen Rockefeller University New York, New York

Solomon H. Snyder Johns Hopkins University Baltimore, Maryland

The Beta-Adrenergic Receptors, edited by John P. Perkins, 1991

Adenosine and Adenosine Receptors, edited by Michael Williams, 1990

The Muscarinic Receptors, edited by Joan Heller Brown, 1989

The Serotonin Receptors, edited by Elaine Sanders-Bush, 1988

The alpha-2 Adrenergic Receptors, edited by Lee Limbird, 1988

The Opiate Receptors, edited by Gavril W. Pasternak, 1988

The alpha-1 Adrenergic Receptors, edited by Robert R. Ruffolo, Jr., 1987

The GABA Receptors, edited by S. J. Enna, 1983 


\section{The \\ Beta-Adrenergic Receptors}

Edited by

John P. Perkins

The University of Texas,

Southwestern Medical Center at Dallas,

Dallas, Texas

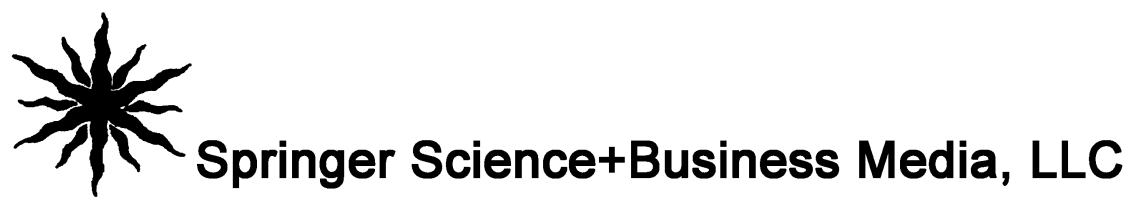


Library of Congress Cataloging-in-Publication Data

The Beta-adrenergic receptors / edited by John P. Perkins.

p. $\mathrm{cm}$. - (The Receptors)

Includes index.

ISBN 978-1-4612-6772-0 ISBN 978-1-4612-0463-3 (eBook)

DOI 10.1007/978-1-4612-0463-3

1. Beta adrenoceptors. I. Perkins, John P. (John Phillip)

II. Series.

[DNLM: 1. Receptors, Adrenergic, Beta-physiology. WL 102.8 B562]

QP364.7.B48 1991

$612.8^{\prime} 042-d c 20$

DNLM/DLC

for Library of Congress

$90-15616$

CIP

(C) 1991 Springer Science+Business Media New York

Originally published by Humana Press Inc. in 1991

Softcover reprint of the hardcover 1st edition 1991

All rights reserved

No part of this book may be reproduced, stored in a retrieval system, or transmitted in any form or by any means, electronic, mechanical, photocopying, microfilming, recording or otherwise without written permission from the Publisher. 


\section{Preface}

Prior to 1974 , the $\beta$-adrenergic receptors were known only indirectly as entities that responded to drugs in a selective manner to mediate a variety of physiologically important responses. During theintervening years, our view of $\beta$-adrenergic receptors has changed dramatically. Theavailability of high affinity ${ }^{125}$ I-labeled radioligands selective for these receptors presaged an explosion of experimentation utilizing direct binding assays to establish the biochemical properties of the receptor protein. In the opening chapter, Stadel and Lefkowitz describe this development and its impact on our understanding of the molecular basis of $\beta$-adrenergic receptor function.

The availability of well-characterized receptor ligands, coupled with the development of efficient methods for detergent solubilization, formed the basis of receptor purification using affinity chromatography. The related technique of photoaffinity labeling provided a means to estimate the molecular mass of these receptors. The availability of substantial amounts of purified $\boldsymbol{\beta}_{2}$-adrenergic receptor allowed determination of segments of its amino acid sequence. This information led to the production of polynucleotide probes and eventually to cloning of the receptor gene and determination of the complete primary sequence of the receptor protein. Caron and Lefkowitz review the investigations leading to this major development and discuss the methods involved. They analyze our current perception of the relation of receptor function to its structure and discuss the general features of the $G$ protein-interacting receptor family, of which the $\beta$-adrenergic receptors are prototypes.

Perkins, Hausdorff, and Lefkowitz examine the current status of ligand-induced desensitization of $\beta$-adrenergic receptor function. The role of receptor phosphorylation is discussed in terms of the involvement of cyclic AMP-dependent protein kinase and the newly discovered $\beta$-adrenergic receptor kinase ( $\beta A R K)$. Receptor endocytosis is examined as a mechanism for ligand-induced $\beta A R$ 
sequestration and a novel mechanism of receptor down-regulation is considered.

Elliott Ross next discusses in detail the methods and theories of membrane protein solubilization, purification, and reconstitution in a functional state, in defined phospholipid vesicles. His treatment focuses on the $\beta$-adrenergic receptor, but provides general insight into this importantmethodology for theanalysis of structure/function relationships of membrane proteins.

The intact $\beta$-adrenergic receptor has routinely been found to be a poor antigen. However, knowledge of the amino acid sequence of the receptor provided the means for production of sequencespecific antibodies. The early frustrations and eventual success of the search for antibodies to the $\beta_{2}$-adrenergic receptor is next described by Malbon, Moxham, and Brandwein. They critically review the techniques involved and discuss the insights gained into receptor secondary structure using immunological methods.

Barry Wolfe analyzes the information gained about the localization of $\beta$-adrenergic receptors in tissues and on cells using autoradiographic techniques. He provides a critical analysis of the techniques and the limits to conclusions that can be drawn from such data.

The chapters by Stiles and Insel, respectively, review our understanding of the regulation of $\beta$-adrenergic receptor function and/or expression by other hormones and neurotransmitters and the involvement of altered receptor function or expression in disease states.

Many of the important new insights into the structure of $\beta$ adrenergic receptors and the molecular bases of their various modes of action are revealed to be generally applicable to other members of this class of receptor molecules.

John P. Perkins 


\section{Contents}

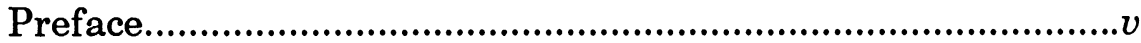

List of Contributors ....................................................................ix

1 - Beta-Adrenergic Receptors: Identification

and Characterization by Radioligand Binding Studies........1 Jeffrey M. Stadel and Robert J. Lefkowitz

2 - Structure-Function Relationships.

Marc G. Caron and Robert J. Lefkowitz

3 - Mechanisms of Ligand-Induced Desensitization of Beta-Adrenergic Receptors.

John P. Perkins, William P. Hausdorff, and Robert J. Lefkowitz

4 - Reconstitution of the Beta-Adrenergic Receptor and Its Biochemical Functions.

Elliott M. Ross

5 - Antibodies to Beta-Adrenergic Receptors

Craig C. Malbon, Cary P. Moxham, and Harvey J. Brandwein

6 - Autoradiographic Studies of Beta-Adrenergic Receptors

Barry B. Wolfe

7 - Beta-Adrenergic Receptors in Pathophysiologic States

and in Clinical Medicine.

Paul A. Insel

8 - Drug and Hormonal Regulation of the Beta-Adrenergic

Receptor-Adenylate Cyclase System 345 Gary L. Stiles

Index 


\section{Contributors}

Harvey J. Brandwein - Genetic Diagnostics Corporation, Great Neck, New York

Marc Caron - Department of Cell Biology, Duke University Medical Center, Durham, North Carolina

Paul A. Insel - Departments of Pharmacology and Medicine, University of California-San Diego, La Jolla, California

Robert J. Lefkowitz - Howard Hughes Medical Institute, Departments of Medicine and Biochemistry, Duke University Medical Center, Durham, North Carolina

Craig C. Malbon - Department of Pharmacological Sciences, School of Medicine, Health Sciences Center, State University of New York, Stony Brook, New York

Cary P. Moxham - Department of Pharmacological Sciences, School of Medicine, Health Sciences Center, State University of New York, Stony Brook, New York

John P. Perkins - Department of Pharmacology, University of Texas, Southwestern Medical Center, Dallas, Texas

Elliott M. Ross - Department of Pharmacology, University of Texas, Southwestern Medical Center, Dallas, Texas

Jeffrey M. Stadel - Department of Molecular Pharmacology, Smith Kline and French Laboratories, Philadelphia, Pennsylvania

Gary L. Stiles - Departments of Medicine (Cardiology) and Biochemistry, Duke University Medical Center, Durham, North Carolina

Barry B. Wolfe - Department of Pharmacology, Georgetown University School of Medicine, Washington, DC 